CLINICAL STUDY

\title{
CDC73-related hereditary hyperparathyroidism: five new mutations and the clinical spectrum
}

\author{
Karin Frank-Raue, Christine Haag, Egbert Schulze, Roger Keuser ${ }^{1}$, Friedhelm Raue, Henning Dralle ${ }^{2}$ \\ and Kerstin Lorenz ${ }^{2}$ \\ Endocrine Practice, Molecular Laboratory, Brückenstr.21, 69120 Heidelberg, Germany, ${ }^{1}$ Endocrine Practice, Koblenz, Germany and ${ }^{2}$ Department of \\ Surgery, Martin Luther Universität Halle, Halle, Germany \\ (Correspondence should be addressed to K Frank-Raue; Email: karin.frankraue@raue-endokrinologie.de)
}

\begin{abstract}
Objective: Hyperparathyroidism-jaw tumour (HPT-JT) syndrome is a rare autosomal dominant cause of benign and malignant parathyroid tumours, ossifying jaw tumours, various cystic and neoplastic renal abnormalities and benign and malignant uterine tumours. Disease-causing mutations have been localised in the tumour suppressor gene CDC73. There is limited information available on the mutations, and resulting phenotypes and long-term follow-up data are especially scarce. Design: We analysed the clinical data from 16 patients (including three families) carrying mutations in the CDC73 gene. We describe five new mutations/gene variants, the corresponding phenotypes of these carriers and the long-term follow-up.

Methods: The 16 patients were evaluated at an endocrine outpatient clinic and at a surgical department. DNA samples were obtained for sequence analysis of the CDC73 gene.

Results: Clinical features of HPT-JT syndrome were detected in 13 of the 15 carriers with germline CDC73 mutations. The major features were benign $(n=7 ; 47 \%)$ or cancerous $(n=3 ; 20 \%)$ HPT-JT was present in eight cases $(53 \%)$. Most patients had severe hypercalcaemia, and median serum calcium levels were $3.36 \mathrm{mmol} / \mathrm{l}$. A patient with non-secretory parathyroid carcinoma was included. HPT was diagnosed at a median age of 28.5 years. Mutational analysis of the CDC73 gene identified eight sequence changes, three of them have been reported previously, whereas five are novel: c.1346delG, c.88_94delTTCTCCT, the non-coding variants, c. $307+5 \mathrm{G}>\mathrm{T}$ and c. $424-5 \mathrm{~T}>\mathrm{C}$ and c. ${ }^{*} 12 \mathrm{C}>\mathrm{A}$ of unknown significance.

Conclusions: This study significantly increases the information available on the mutations and phenotypes of HPT-JT syndrome.
\end{abstract}

European Journal of Endocrinology 165 477-483

\section{Introduction}

In patients with CDC73 mutations (formerly known as HRPT2), a spectrum of parathyroid tumour-associated phenotypes is described as follows: hyperparathyroidismjaw tumour syndrome (HPT-JT), familial isolated hyperparathyroidism (FIHP) and parathyroid carcinoma (1). HPT-JT is a rare autosomal dominant cause of benign and malignant parathyroid tumours, ossifying fibromas of the mandible and maxilla, various cystic and neoplastic renal abnormalities and benign and malignant uterine tumours. The disease is caused by inactivating germline mutations in the tumour suppressor gene CDC73 with subsequent loss of parafibromin expression $(2,3)$. CDC73 encodes parafibromin, a regulator of gene expression. Several reports have demonstrated a loss of parafibromin expression in HPTJT-related parathyroid adenomas (4) and also by somatic CDC73 mutations in sporadic parathyroid carcinomas (5). To date, more than 100 independent CDC73 mutations have been identified (germline and somatic), and these occur throughout the coding region and splice sites of the CDC73 gene (1). Primary HPT, the main finding in HPT-JT syndrome, occurs in $80-90 \%$ of affected individuals. In about $10-15 \%$ of CDC73associated cases, HPT is caused by parathyroid carcinoma and even nonfunctioning parathyroid carcinomas have been reported (6). Cemento-ossifying fibromas of the mandible and maxilla occur in $30-40 \%$ of individuals with HPT-JT syndrome, whereas $\sim 20 \%$ show kidney lesions, most commonly renal cysts, but rarely malignant tumours have been reported. Uterine tumours appear to be common in women with HPT-JT (7). Incomplete penetrance of gnathic, renal and uterine expression of HPT-JT is known to occur.

Familial primary HPT is a heterogeneous disease; the main hereditary forms of HPT are multiple endocrine neoplasia (MEN) type 1 and type 2, HPT-JT syndrome and FIHP (8), which is characterised by HPT without other associated features. FIHP is rarely caused by 
CDC73 mutations $(9,10)$. Sporadic parathyroid carcinomas frequently have somatic CDC73 mutations that are likely to be pathogenetic. Somatic mutations have been detected in $57-100 \%$ of patients with sporadic parathyroid carcinoma $(5,11,12)$. About $20 \%$ of patients with apparently sporadic parathyroid carcinoma carry germline mutations in the CDC73 gene (5). There is considerable variability in the penetrance and expressivity of truncating CDC73 mutations, making it difficult to develop comprehensive and efficient guidelines for carrier therapy and surveillance. CDC73 mutation analysis in affected families offers the unique chance to diagnose hereditary parathyroid cancer at an early stage.

In this study, we investigated the phenotypic characteristics of 16 patients carrying mutations in the CDC73 gene and provide significant new data about this group of patients and their families. In particular, the long-term follow-up data are crucial for formulating appropriate management guidelines. In this study, we describe five new mutations/gene variants, the corresponding phenotype in these carriers, and the longterm follow-up for up to 17 years.

\section{Materials and methods}

The study population consisted of 16 patients evaluated at the endocrine outpatient clinic in Heidelberg, Germany, and operated at the Surgical Department of the University of Halle, Germany. DNA samples were obtained and sent, with clinical data, for mutation analysis at the Molecular Laboratory in Heidelberg, Germany. Informed consent for collection of clinical, biochemical and genetic data was obtained from all patients. HPT-JT syndrome was diagnosed in cases with familial primary HPT, evidence of parathyroid adenoma or carcinoma, cemento-ossifying jaw tumours and germline CDC73 mutations. Criteria used for diagnosis of parathyroid carcinoma were vascular and/or capsular invasion of tumour tissue and/or metastatic disease. Selection criteria to identify index cases for CDC73 sequencing was established: familial HPT and/or HPT plus an HPT-JT associated lesion (i.e. jaw tumour and renal cysts). Germline and somatic CDC73 sequencing was only done for patient H. Clinical, biochemical and histological data were collected and follow-up included clinical and laboratory re-evaluation. Family A was included in a former study (13), whereas the index case of family $\mathrm{C}$ was included in several studies $(3,12,14)$. The clinical findings and family data were extended and long-term follow-up was outlined.

\section{Germline and somatic mutation analysis of the CDC73 gene}

DNA was extracted from tumour samples and peripheral blood leucocytes according to standard procedures. The 17 exons of the CDC73 gene were amplified by PCR as described previously (5). The PCR products were purified using the AMPure system (Beckman Coulter, Brea, CA, USA) and sequenced with the BigDye Terminator v3.1 Cycle Sequencing Kit (Applied Biosystems, Foster City, CA, USA) according to the manufacturer's protocol. All mutations were confirmed by a second independent PCR amplification and sequencing reaction.

\section{Results}

The study population consisted of 16 patients of which 15 carried germline mutations in the CDC73 gene, whereas in one patient $(\mathrm{H})$, only a somatic CDC73 mutation was detected in parathyroid cancer tissue. In this study, four patients with parathyroid carcinomas were included, three with germline CDC73 mutations (A II.1, B I.1 and C II.1) and patient $\mathrm{H}$ with only the somatic mutation.

\section{Patients}

The study population included three families (with three, five, and three affected members/mutation carriers) carrying different germline mutations (Fig. 1). The index cases of families A, B and $\mathrm{C}$ all had parathyroid carcinoma; therefore, sequence analysis of the CDC73 gene was performed. In all of the single patients (D, E, F and G), the combination of HPT with jaw tumours led us to sequence the CDC73 gene. Clinical features of HPT-JT syndrome were detected in 13 of the 15 carriers of germline mutations (Table 1 ). Disease manifestation was exhibited in two family members of family B (B II.2 and B II.3), but germline testing was not yet performed; therefore, we considered them to be affected family members. To date, two subjects (A I.1 and B II.1), aged 72 and 43 years, have no clinical manifestation of the disease and are considered healthy mutation carriers.

The major clinical features in our 15 patients carrying germline $C D C 73$ mutations were benign $(n=7,47 \%)$ or cancerous $(n=3,20 \%)$ HPT. Of the total patients, one underwent surgery for benign HPT but the exact histology was not available, and four patients had no parathyroid involvement. No criteria for atypical parathyroid adenomas were identified. HPT was the first manifestation leading to the diagnosis of the disease in all but two patients. Aetiology in all but one patient with benign parathyroid disease was a single parathyroid adenoma; hyperplasia of three glands was identified in one patient (C II.2). HPT was diagnosed at a median age of 28.5 years (range 16-58), whereas carcinoma patients had a median age at diagnosis of 30 years (range 22-57). In affected patients, median serum calcium levels were $3.36 \mathrm{mmol} / \mathrm{l}$ (range 2.9-4.3 mmol/l; normal 2.2-2.65 mmol/l) and median PTH levels were $39.8 \mathrm{pmol} / \mathrm{l}$ (range 12.5-235 pmol/l; normal 1.3-5.4 pmol/l). In patients exhibiting parathyroid carcinoma, median serum calcium 
A

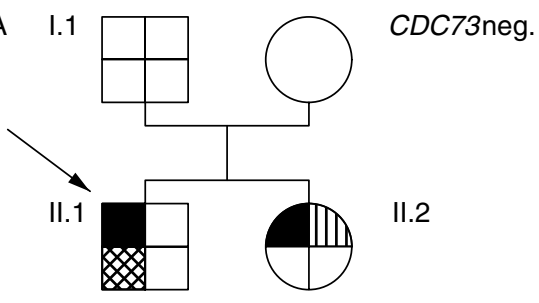

B

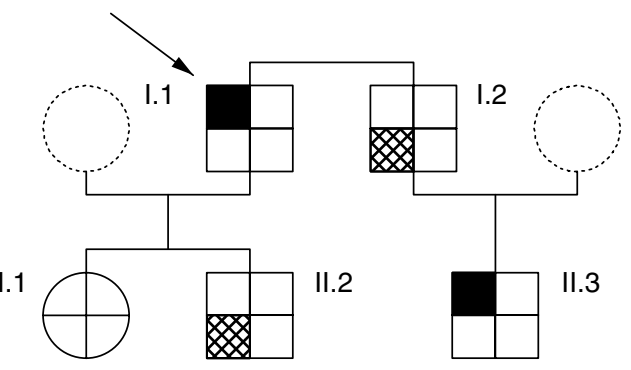

C
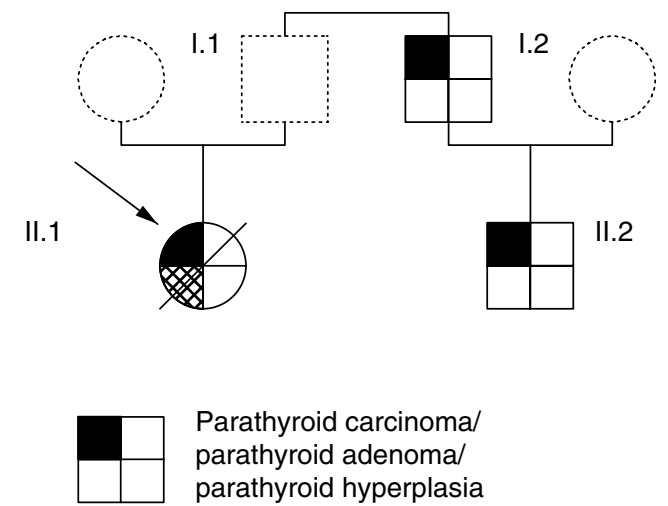

Parathyroid carcinoma/ parathyroid adenoma/ parathyroid hyperplasia

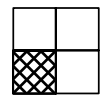

Jaw tumor

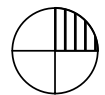

Uterine myoma

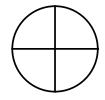

Gene carrier without

disease manifestation<smiles>C1CCCCCC1</smiles>

Not investigated re-operations in the neck and mediastinum and, therefore, impaired lung function and increased risk for pneumonia and pulmonary complications. She died from severe pneumonia at the age of 40 years after 17 years of follow-up. One patient suffered from severe hypercalcaemia related to lung and bone metastases (B I.1).

Jaw tumours were present in eight cases $(53 \%)$, and half of them were histologically proven as cementoossifying fibromas. In two members of family B, jaw tumours (one proven histologically) were diagnosed before other disease manifestations. Renal cysts were found by ultrasound in one patient and uterine myoma in two patients. Of the six females carrying germline mutations in our study, myomas were detected in two patients, gynaecological ultrasound was normal in three patients and information was unavailable in one patient. Of the 15 cases, two cases were assigned the status of apparent silent carrier.

In one patient with parathyroid cancer $(\mathrm{H})$, only a somatic novel $C D C 73$ mutation was detected in the tumour tissue, no germline mutation was found. The diagnosis of this patient was based on hypercalcaemia, and during follow-up, recurrent cancer tissue was re-operated several times. This patient suffered from persistent hypercalcaemia due to parathyroid cancer and died as a result of lung metastases, hypercalcaemia and cachexia after 8 years of follow-up.

\section{Mutational analysis of the CDC73 gene}

In this study, mutational analysis of the $C D C 73$ gene identified eight sequence changes, three of which have been previously reported. Of the CDC73 sequence changes, five encountered in this study are novel: c. 1346 delG, c. $307+5 \mathrm{G}>\mathrm{T}$, c. $424-5 \mathrm{~T}>\mathrm{C}$, c. ${ }^{*} 12 \mathrm{C}>\mathrm{A}$ and c.88_94delTTCTCCT (Table 2). The 7 bp deletion c.88_94delTTCTCCT in Exon 1 in the parathyroid tumour tissue of patient $\mathrm{H}$ causes premature termination of protein synthesis; this mutation was detected only in the tumour tissue of this patient, not in her germline. This mutation occurs either as a homozygous variant or more likely in a hemizygous state (loss of heterozygosity). In two index cases (B I.1, E 1), a known CDC73 polymorphism, c. $1418-17 \mathrm{C}>\mathrm{G}$ in intron 15 , was detected. No polymorphisms were detected in the four other index cases.

\section{Discussion}

\section{Clinical findings}

The major clinical features in our 15 patients carrying germline CDC73 mutations were benign $(47 \%)$ or cancerous (20\%) HPT, similar to the findings of Simonds et al. (8). HPT was the first manifestation of the disease in all but two of our patients. This is in concordance with recently published studies $(15,16)$. Aetiology in all but one patient with benign parathyroid disease was 
Table 1 Clinical and laboratory findings in patients with HPT-JT syndrome/parathyroid carcinoma.

\begin{tabular}{|c|c|c|c|c|c|c|c|}
\hline $\begin{array}{l}\text { Patient no. } \\
\text { (reference) }\end{array}$ & $\begin{array}{l}\text { Sex/current } \\
\text { age (years) }\end{array}$ & $\begin{array}{l}\text { Age at } \\
\text { diagnosis } \\
\text { of HPT } \\
\text { (years) }\end{array}$ & $\begin{array}{l}\text { Initial calcium } \\
\mathrm{mmol} / \mathrm{l} \\
(2.2-2.65)\end{array}$ & $\begin{array}{l}\text { Initial PTH } \\
\text { pmol/I } \\
(1.3-5.4)\end{array}$ & $\begin{array}{l}\text { Parathyroid } \\
\text { tumours }\end{array}$ & $\begin{array}{l}\text { Outcome/follow-up } \\
\text { years }\end{array}$ & $\begin{array}{l}\text { Associated } \\
\text { diseases }\end{array}$ \\
\hline A I.1 (13) & $\mathrm{M} / 72$ & - & 2.4 & 2.9 & - & $\begin{array}{l}\text { No disease } \\
\text { manifestation } / 5\end{array}$ & - \\
\hline A II.1 (13) & $M / 39$ & 30 & $\begin{array}{l}4.3 \\
\text { (renal failure) }\end{array}$ & 143 & Carcinoma & Disease-free/9 & Jaw-tumour \\
\hline A II.2 (13) & $\mathrm{F} / 43$ & 32 & 3.3 & 48.9 & Adenoma & Disease-free/11 & Uterine myoma \\
\hline B I.1 & $M / 63$ & 57 & 3.8 & 235 & Carcinoma & $\begin{array}{l}\text { Persistent HPT } \\
\text { metastases: } \\
\text { lung, bone/ } 6\end{array}$ & - \\
\hline B I.2 & $M / 51$ & - & 2.2 & Normal & - & $\begin{array}{l}\text { No HPT, no kidney } \\
\text { disease/8 }\end{array}$ & Jaw-tumour ${ }^{a}$ \\
\hline B II.1 & $\mathrm{F} / 43$ & - & 2.2 & Normal & - & $\begin{array}{l}\text { No disease } \\
\text { manifestation/6 }\end{array}$ & - \\
\hline B II.2 & $M / 36$ & - & Normal & Normal & - & No HPT/6 & Jaw-tumour \\
\hline B II.3 & $\mathrm{M} / 22$ & 16 & 3.46 & 25 & Adenoma & Disease-free /6 & - \\
\hline C I.2 & $\mathrm{M} / 61$ & 50 & 3.27 & 39.6 & $\begin{array}{l}\text { Single } \\
\text { adenoma }\end{array}$ & Disease-free /10 & - \\
\hline $\begin{array}{l}\text { C II.1 } \\
\qquad(3,12,14)\end{array}$ & F/DWD & $22^{\mathrm{b}}$ & Normal, NSC & $\begin{array}{l}\text { Normal, } \\
\text { NSC }\end{array}$ & Carcinoma & $\begin{array}{l}\text { Multiple recurrences } \\
\text { DWD/17 }\end{array}$ & Jaw tumour ${ }^{a}$ \\
\hline C II.2 & $M / 31$ & 20 & 3.36 & 12.5 & $\begin{array}{l}3 \text { Hyperplastic } \\
\text { glands }\end{array}$ & Disease-free/11 & - \\
\hline D 1 & $\mathrm{~F} / 33$ & 20 & 3.6 & 39.8 & Adenoma & Disease-free/10 & Jaw tumour \\
\hline E 1 & $M / 25$ & NA & Elevated & Elevated & NA & NA & Jaw tumour \\
\hline$F_{1}$ & $F / 29$ & 27 & 2.9 & 15 & Adenoma & Disease-free/2 & Jaw tumour ${ }^{\mathrm{a}}$ \\
\hline G 1 & $\mathrm{~F} / 58$ & 58 & 3.2 & 54.5 & Adenoma & Disease-free/0.5 & $\begin{array}{l}\text { Jaw-tumour }^{\mathrm{a}} \\
\text { Uterine myoma }\end{array}$ \\
\hline $\begin{array}{l}\text { Somatic mutation } \\
\mathrm{H} 1\end{array}$ & F/DFD & 25 & 3.4 & 39.1 & Carcinoma & $\begin{array}{l}\text { Persistent HPT } \\
\text { metastases: lung/8 }\end{array}$ & Renal cysts \\
\hline
\end{tabular}

DWD, dead with disease; DFD, dead from disease; NSC, non-secretory carcinoma; NA, not available.

aHistologically proven cemento-ossifying fibroma.

${ }^{\mathrm{b}} \mathrm{Age}$ at diagnosis of non-secretory parathyroid carcinoma.

a single parathyroid adenoma. Jaw tumours were present in eight cases (53\%) in our study. In two patients, jaw tumours were diagnosed first without any other disease manifestations. Cemento-ossifying fibromas have been reported to occur in $25-50 \%$ of cases $(2,15)$, but it is not clear whether the jaw tumours were the first manifestations. If family screening is established in an appropriate manner, early findings of jaw tumours may allow for earlier diagnosis of HPT-JT syndrome.

Renal cysts were detected in one patient. In the two patients diagnosed with uterine myomas, hysterectomy was not necessary. This is in contrast to the findings of Bradley et al. (7) who described uterine involvement and a decrease in reproductive fitness in up to $75 \%$ of women with HPT-JT syndrome. Of the 15 cases, two were assigned the status of apparent silent carrier, while the degree of non-penetrance has been described to be more than $30 \%(7)$.

The average age of onset of HPT in HPT-JT syndrome is not well established and is usually in late adolescence or early adulthood but subjects younger than 10 years of age have been reported (8). In one study, a mean age at diagnosis of 36 years is reported (17). The median age at diagnosis of HPT was 28.5 years (range 16-58) in our study; this is in accordance with recently published data (17). We suggest biochemically screening asymptomatic mutation carriers beginning at the age of 15 years, because very early manifestation is rare. However, some may argue that a baseline screening $\mathrm{Ca} / \mathrm{PTH}$, panoramic jaw X-rays and renal ultrasound any time after the age 5 years would be appropriate, because any equivocal or positive features would invoke more careful screening for other disease manifestations (18).

HPT in HPT-JT syndrome is usually caused by a single parathyroid adenoma, but recurrence of HPT after selective parathyroidectomy occurred in about $20 \%$ of cases after 10-15 years (17). In HPT-JT patients with HPT, long periods of postsurgical normocalcaemia could be documented; therefore, selective parathyroidectomy may be an effective strategy, but long-term follow-up is necessary (19). In our patients, predominantly single parathyroid adenomas were detected at the primary operation. After a median follow-up of 10 years (range $0.5-11$ years), no recurrence was observed in patients carrying benign parathyroid disease. The reason for this lack of recurrences might be the relatively short followup period. In $20 \%$ of cases in our study, HPT in HPT-JT syndrome was caused by parathyroid cancer. A $15 \%$ 
Table $2 C D C 73$ mutations in patients with HPT-JT syndrome/parathyroid carcinoma.

\begin{tabular}{|c|c|c|c|c|c|}
\hline Family & Mutation & Region & Mutation type & Predicted effect & Reference \\
\hline A & $\begin{array}{l}\text { c. } 700 \mathrm{C}>\mathrm{T} \\
\text { p.Arg234X }\end{array}$ & Exon 7 & Germline & Mutation/premature stop codon & Shattuck et al. 2003 (5) \\
\hline B & $\begin{array}{l}\text { c.1346delG } \\
\text { p.Gly449Valfs } \times 30\end{array}$ & Exon 15 & Germline & Frame shift premature stop codon & Novel \\
\hline C & $\begin{array}{l}\text { c.76delA } \\
\text { p.lle26SerfsX11 }\end{array}$ & Exon 1 & Germline & Mutation/deletion premature stop codon & Howell et al. 2003 (12) \\
\hline D & $\begin{array}{l}\text { c.1432_1433delCT } \\
\text { p.Leu478GlufsX }\end{array}$ & Exon 16 & Germline & Mutation/frame shift premature stop codon & Haag et al. 2008 (21) \\
\hline E & c. $307+5 \mathrm{G}>\mathrm{T}$ & IVS 3 & Germline & VUS/splice site & Novel \\
\hline $\mathrm{F}$ & c. $424-5 \mathrm{~T}>\mathrm{C}$ & IVS 5 & Germline & VUS/splice site & Novel \\
\hline G & c. ${ }^{*} 12 C>A$ & $3^{\prime}$-UTR & Germline & VUS/expression & Novel \\
\hline $\mathrm{H}$ & $\begin{array}{l}\text { c.88_94delTTCTCCT } \\
\text { p.Phe30GlyfsX5 }\end{array}$ & Exon 1 & Somatic & $\begin{array}{l}\text { Mutation (homozygous)/deletion premature } \\
\text { stop codon }\end{array}$ & Novel \\
\hline
\end{tabular}

VUS, variants of unknown significance.

occurrence of parathyroid carcinoma was detected in a large study (8); in this study, the number of operations per case was highest in the HPT-JT subgroup because of the high prevalence of parathyroid carcinoma. In this study, one patient (8) had parathyroid carcinoma in two separate glands at initial cervical exploration, and the highest proportion of cystic parathyroid tumours was among the HPT-JT patients. An index patient (C II.1) with non-secretory parathyroid carcinoma was included in our study. Another normocalcaemic patient with parathyroid cancer has been described (6), and these two patients carry different mutations. From these two cases, we conclude that longitudinal surveillance by serum calcium biochemistry alone may not be sufficient; routine neck ultrasound should also be performed.

Some findings in the HPT-JT patients in this and other studies differ from the findings typical for patients with sporadic HPT or other varieties of hereditary HPT. First, there is a unique high frequency (three of 15 cases) of parathyroid cancer in HPT-JT in our study. The frequency of parathyroid carcinoma is virtually 0 in MEN1 and clearly below $1 \%$ in sporadic cases of HPT $(8,20)$. Secondly, the majority of patients with HPT-JT have single gland involvement, similar to patients with the sporadic variety. This is in contrast to HPT in MEN1, which involves several glands simultaneously and asymmetrically. Thirdly, in our study, the severity of parathyroid involvement in relation to serum calcium and PTH elevation was more severe in HPT-JT than in sporadic HPT, which nowadays is often mild and asymptomatic.

\section{Genetic characteristics}

In this patient cohort, we identified eight $C D C 73$ mutations in four of the 17 exons. Of the eight mutations, one resulted directly in a premature stop codon, four gave rise to an altered reading frame and two mutations involved a splice site and therefore are likely to cause a change in the resulting protein.
The mutation p.Arg234X of family A has been previously reported in several unrelated patients with parathyroid carcinomas $(5,11)$ and also in HPT-JT patients $(1,15)$. Clinical data are limited in these studies; therefore, a comparison of phenotypes is not possible. The mutations p.Ile26SerfsX11 of family $\mathrm{C}$ and p.Leu478GlufsX of patient D have been previously reported by the authors $(3,12,21)$. In this study, five of the CDC73 sequence changes encountered are novel (Table 2). The newly described heterozygous deletion c.1346delG p.Gly449ValfsX30 in Exon 15 in family B causes a frameshift and premature stop codon and, therefore, is predicted to cause a loss of gene function. This CDC73 mutation segregated with the disease within this family; therefore, it is very likely to be involved in the pathogenesis of the disease. The novel c. $307+5 \mathrm{G}>\mathrm{T}$ sequence change in intron 3 of patient $\mathrm{E}$ and the unreported mutation c. $424-5 \mathrm{~T}>\mathrm{C}$ in patient F involve a splice site and, therefore, might affect the resulting protein. The variant of unknown significance, c. ${ }^{*} 12 \mathrm{C}>\mathrm{A}$ in the $3^{\prime}$-UTR in patient $\mathrm{G}$, may be involved in the regulatory processes of expression. The co-occurrence of HPT and a jaw tumour in the single patients E, $F$ and $G$ suggest a pathogenetic role of the newly described gene variants in these patients.

In the relatively short time since the identification of CDC73 in 2002, nearly 70 germline mutations have

Table 3 When should $C D C 73$ mutation analysis be considered?

Parathyroid carcinoma

Cemento-ossifying fibroma of the jaw

Young patient with hyperparathyroidism when MEN1 mutation analysis is negative

Multiglandular parathyroid involvement when MEN1 mutation analysis is negative

Recurrent hyperparathyroidism when MEN1 mutation analysis is negative

Familial hyperparathyroidism when MEN1/2 mutation analysis is negative

If in mild asymptomatic familial hypercalcaemia, CASR and MEN1/2 mutation analysis is negative, $C D C 73$ mutation analysis may be considered 
been reported (1). Mutations in exons 1, 2 and 7 are overrepresented (about 80\%), but there is no apparent genotype-phenotype correlation (1). Our data support this finding. Non-penetrance of the CDC73 mutations in HPT-JT kindreds has been reported in $>30 \%$ of mutation carriers (15) and the latest clinical manifestation of HPT was reported after the age of 60 years. In our study, the oldest asymptomatic gene carrier was 72 years old.

\section{How to involve genetic information in clinical practice}

Familial HPT has been associated with mutant MEN1 and MEN2, mutant calcium-sensing receptor (CASR) and mutant CDC73 genotypes. CDC73 mutation analysis is reasonable in patients with parathyroid carcinoma or in patients with HPT and cementoossifying fibromas of the mandible and maxilla (Table 3). Also, in young patients with HPT, CDC73 mutation analysis may be undertaken when MEN1 mutation analysis is negative. Of the HPT-JT families described, the youngest patient with HPT was 10 years of age (8), whereas the youngest patient in our study was 16 years of age. In patients with multiglandular involvement, HPT-JT syndrome may be a rare causative disease, as was found for one case in our study. Recurrent HPT is described in HPT-JT syndrome especially during long-term follow-up (17); therefore, in patients with multiglandular involvement or recurrent HPT, CDC73 mutation analysis may be considered. Among the different variants of hereditary HPT, MEN1HPT is the most frequent and carries the highest recurrence rate. Therefore, MEN1 gene analysis should be completed first in suspected hereditary HPT; if MEN1 mutation analysis is negative, CDC73 analysis should be considered. In $5-10 \%$ of cases, MEN1 phenocopies may be present and it is important to be aware of their presence in the clinical setting of hereditary HPT (22). Some of these cases have been attributed to mutations in the cyclin-dependent kinase inhibitor genes (23). In MEN2, the higher penetrance of medullary thyroid cancer and pheochromocytoma dominates the clinical presentation. HPT in MEN2 usually is mild and usually occurs only in RET 634 carriers. A $20 \%$ penetrance rate is documented for MEN2; therefore, it is not the primary consideration in the differential diagnosis of hereditary HPT (24). CASR mutation screening in FIHP should be considered when there is mild asymptomatic hypercalcaemia without other pathologies.

\section{Conclusions}

The identification of CDC73 mutations in patients with HPT-JT syndrome and the ability to perform genetic testing offer the unique chance to diagnose hereditary parathyroid cancer at an early stage. Also, early diagnosis of HPT in these families is possible, preventing hypercalcaemic crisis, nephrolithiasis and renal insufficiency and osseous complications like fractures due to osteoclastic 'brown' tumours or osteoporosis. Excision of the identified parathyroid tumour is usually sufficient in HPT-JT syndrome. There is no evidence supporting prophylactic parathyroid surgery in CDC73 mutation carriers. Long-term follow-up is required because of the risk of recurrent HPT and parathyroid carcinoma.

\section{Declaration of interest}

The authors declare that there is no conflict of interest that could be perceived as prejudicing the impartiality of the research reported.

\section{Funding}

This research did not receive any specific grant from any funding agency in the public, commercial or not-for-profit sector.

\section{Acknowledgements}

We thank Prof. Kiffner, St. Vinzenz Hospital, Karlsruhe, for providing clinical data.

\section{References}

1 Newey PJ, Bowl MR, Cranston T \& Thakker RV. Cell division cycle protein 73 homolog (CDC73) mutations in the hyperparathyroidism-jaw tumor syndrome (HPT-JT) and parathyroid tumors. Human Mutation 201031 295-307. (doi:10.1002/humu.21188)

2 Carpten JD, Robbins CM, Villablanca A, Forsberg L, Presciuttini S, Bailey-Wilson J, Simonds WF, Gillanders EM, Kennedy AM, Chen JD, Agarwal SK, Sood R, Jones MP, Moses TY, Haven C, Petillo D, Leotlela PD, Harding B, Cameron D, Pannett AA, Hoog A, Heath H III, James-Newton LA, Robinson B, Zarbo RJ, Cavaco BM, Wassif W, Perrier ND, Rosen IB, Kristoffersson U, Turnpenny PD, Farnebo LO, Besser GM, Jackson CE, Morreau H, Trent JM, Thakker RV, Marx SJ, Teh BT, Larsson C \& Hobbs MR. HRPT2, encoding parafibromin, is mutated in hyperparathyroidism-jaw tumor syndrome. Nature Genetics 200232 676-680. (doi:10. $1038 /$ ng 1048)

3 Gill AJ, Clarkson A, Gimm O, Keil J, Dralle H, Howell VM \& Marsh DJ. Loss of nuclear expression of parafibromin distinguishes parathyroid carcinomas and hyperparathyroidismjaw tumor (HPT-JT) syndrome-related adenomas from sporadic parathyroid adenomas and hyperplasias. American Journal of Surgical Pathology 200630 1140-1149. (doi:10.1097/01.pas. $0000209827.39477 .4 \mathrm{f})$

4 Juhlin C, Larsson C, Yakoleva T, Leibiger I, Leibiger B, Alimov A, Weber G, Hoog A \& Villablanca A. Loss of parafibromin expression in a subset of parathyroid adenomas. Endocrine-Related Cancer 200613 509-523. (doi:10.1677/erc.1.01058)

5 Shattuck TM, Valimaki S, Obara T, Gaz RD, Clark OH, Shoback D, Wierman ME, Tojo K, Robbins CM, Carpten JD, Farnebo LO, Larsson C \& Arnold A. Somatic and germ-line mutations of the HRPT2 gene in sporadic parathyroid carcinoma. New England Journal of Medicine 2003349 1722-1729. (doi:10.1056/ NEJMoa031237)

6 Guarnieri V, Scillitani A, Muscarella LA, Battista C, Bonfitto N, Bisceglia M, Minisola S, Mascia ML, D’Agruma L \& Cole DE. Diagnosis of parathyroid tumors in familial isolated hyperparathyroidism with 
HRPT2 mutation: implications for cancer surveillance. Journal of Clinical Endocrinology and Metabolism 2006 91 2827-2832. (doi:10. 1210/jc.2005-1239)

7 Bradley KJ, Hobbs MR, Buley ID, Carpten JD, Cavaco BM, Fares JE, Laidler P, Manek S, Robbins CM, Salti IS, Thompson NW, Jackson CE \& Thakker RV. Uterine tumours are a phenotypic manifestation of the hyperparathyroidism-jaw tumour syndrome. Journal of Internal Medicine 2005257 18-26. (doi:10.1111/ j.1365-2796.2004.01421.x)

8 Simonds WF, James-Newton LA, Agarwal SK, Yang B, Skarulis MC, Hendy GN \& Marx SJ. Familial isolated hyperparathyroidism: clinical and genetic characteristics of 36 kindreds. Medicine 200281 1-26. (doi:10.1097/00005792-20020100000001)

9 Simonds WF, Robbins CM, Agarwal SK, Hendy GN, Carpten JD \& Marx SJ. Familial isolated hyperparathyroidism is rarely caused by germline mutation in HRPT2, the gene for the hyperparathyroidism-jaw tumor syndrome. Journal of Clinical Endocrinology and Metabolism 200489 96-102. (doi:10.1210/jc. 2003-030675)

10 Villablanca A, Calender A, Forsberg L, Hoog A, Cheng JD, Petillo D, Bauters C, Kahnoski K, Ebeling T, Salmela P, Richardson AL, Delbridge L, Meyrier A, Proye C, Carpten JD, Teh BT, Robinson BG \& Larsson C. Germline and de novo mutations in the HRPT2 tumour suppressor gene in familial isolated hyperparathyroidism (FIHP). Journal of Medical Genetics 200441 e32. (doi:10.1136/ jmg.2003.012369)

11 Cetani F, Pardi E, Borsari S, Viacava P, Dipollina G, Cianferotti L, Ambrogini E, Gazzerro E, Colussi G, Berti P, Miccoli P, Pinchera A \& Marcocci C. Genetic analyses of the HRPT2 gene in primary hyperparathyroidism: germline and somatic mutations in familial and sporadic parathyroid tumors. Journal of Clinical Endocrinology and Metabolism 200489 5583-5591. (doi:10.1210/jc.2004-0294)

12 Howell VM, Haven CJ, Kahnoski K, Khoo SK, Petillo D, Chen J, Fleuren GJ, Robinson BG, Delbridge LW, Philips J, Nelson AE, Krause U, Hammje K, Dralle H, Hoang-Vu C, Gimm O, Marsh DJ, Morreau H \& Teh BT. HRPT2 mutations are associated with malignancy in sporadic parathyroid tumours. Journal of Medical Genetics 200340 657-663. (doi:10.1136/jmg.40.9.657)

13 Raue F, Haag C \& Frank-Raue K. Hyperparathyroidism-jaw tumor syndrome. A hereditary form of primary hyperparathyroidism with parathyroid carcinoma. Deutsche Medizinische Wochenschrift 2007132 1459-1462. (doi:10.1055/s-2007-982052)

14 Howell VM, Gill A, Clarkson A, Nelson AE, Dunne R, Delbridge LW, Robinson BG, Teh BT, Gimm O \& Marsh DJ. Accuracy of combined protein gene product 9.5 and parafibromin markers for immunohistochemical diagnosis of parathyroid carcinoma. Journal of Clinical Endocrinology and Metabolism 2009 94 434-441. (doi:10.1210/jc.2008-1740)
15 Bradley KJ, Cavaco BM, Bowl MR, Harding B, Cranston T, Fratter C, Besser GM, Conceicao Pereira M, Davie MW, Dudley N, Leite V, Sadler GP, Seller A \& Thakker RV. Parafibromin mutations in hereditary hyperparathyroidism syndromes and parathyroid tumours. Clinical Endocrinology 200664 299-306. (doi:10.1111/ j.1365-2265.2006.02460.x)

16 Marx SJ. Hyperparathyroid and hypoparathyroid disorders. New England Journal of Medicine 2000343 1863-1875. (doi:10.1056/ NEJM200012213432508)

17 Iacobone M, Masi G, Barzon L, Porzionato A, Macchi V, Ciarleglio FA, Palu G, De Caro R, Viel G \& Favia G. Hyperparathyroidism-jaw tumor syndrome: a report of three large kindred. Langenbeck's Archives of Surgery 2009394 817-825. (doi:10. 1007/s00423-009-0511-y)

18 Kelly TG, Shattuck TM, Reyes-Mugica M, Stewart AF, Simonds WF, Udelsman R, Arnold A \& Carpenter TO. Surveillance for early detection of aggressive parathyroid disease: carcinoma and atypical adenoma in familial isolated hyperparathyroidism associated with a germline HRPT2 mutation. Journal of Bone and Mineral Research 200621 1666-1671. (doi:10.1359/jbmr.060702)

19 Gimm O, Lorenz K, Nguyen Thanh P, Schneyer U, Bloching M, Howell VM, Marsh DJ, Teh BT, Krause U \& Dralle H. Prophylactic parathyroidectomy for familial parathyroid carcinoma. Der Chirurg 200677 15-24. (doi:10.1007/s00104-005-1110-2)

20 Marcocci C, Cetani F, Rubin MR, Silverberg SJ, Pinchera A \& Bilezikian JP. Parathyroid carcinoma. Journal of Bone and Mineral Research 200823 1869-1880. (doi:10.1359/jbmr.081018)

21 Haag C, Pauli S, Schulze E, Frank-Raue K \& Raue F. Hyperparathyroidism-jaw tumor syndrome (HPT-JT): a new mutation in the HRPT2-gene. Endocrine Abstracts 200816 P73.

22 Turner JJ, Christie PT, Pearce SH, Turnpenny PD \& Thakker RV. Diagnostic challenges due to phenocopies: lessons from multiple endocrine neoplasia type1 (MEN1). Human Mutation 201031 E1089-E1101. (doi:10.1002/humu.21170)

23 Agarwal SK, Mateo CM \& Marx SJ. Rare germline mutations in cyclin-dependent kinase inhibitor genes in multiple endocrine neoplasia type 1 and related states. Journal of Clinical Endocrinology and Metabolism 200994 1826-1834. (doi:10.1210/ jc.2008-2083)

24 Raue F, Kraimps JL, Dralle H, Cougard P, Proye C, Frilling A, Limbert E, Llenas LF \& Niederle B. Primary hyperparathyroidism in multiple endocrine neoplasia type 2A. Journal of Internal Medicine 1995238 369-373. (doi:10.1111/j.1365-2796.1995. tb01212.x)

Received 18 May 2011

Accepted 7 June 2011 